\title{
The occurrence of a shallow-water Ammobaculoides assemblage in the Middle Jurassic (Bajocian) Dhruma Formation of Central Saudi Arabia
}

\author{
Michael A. Kaminski ${ }^{1}$, Muhammad Hammad Malik ${ }^{1}$, and Eiichi Setoyama ${ }^{2}$ \\ ${ }^{1}$ King Fahd University of Petroleum \& Minerals, GeoSciences Department, Dhahran, 31261, Saudi Arabia \\ ${ }^{2}$ Energy \& Geoscience Institute, University of Utah, 423 Wakara Way, Suite 300, \\ Salt Lake City, Utah 84108, USA
}

Correspondence: Michael A. Kaminski (kaminski@kfupm.edu.sa)

Received: 20 November 2015 - Revised: 8 October 2016 - Accepted: 15 October 2016 - Published: 11 January 2018

\begin{abstract}
We report the occurrence of an Ammobaculoides-dominated assemblage in the lowermost member of the Middle Jurassic Dhruma Formation exposed west of Riyadh, Saudi Arabia. The new species Ammobaculoides dhrumaensis n.sp. is described from the green shale of the D1 unit (also known as the Balum Member) of the Dhruma Formation, which has been assigned an early Bajocian age based on ammonites. Our new finding constitutes the oldest reported worldwide occurrence of the agglutinated foraminiferal genus Ammobaculoides Plummer, 1932.
\end{abstract}

The Dhruma Formation was deposited during the Middle Jurassic transgression (Vaslet et al., 1983) and is a part of the petroleum-rich Jurassic succession of Saudi Arabia. The formation is named after the town of Dhruma situated northwest of Riyadh (Fig. 1). The Dhruma Formation belongs to the Jurassic Shaqra Group, which is the most prolific stratigraphic petroleum producer in the world. The Shaqra Group contains 12 reservoirs in seven formations that are exploited in the Ghawar Field, which is the world's largest onshore oil field. The Dhruma Formation lies in the lower portion of the Shaqra Group and is assigned a Middle Jurassic (BajocianBathonian) age based on ammonites (Arkell, 1952; Enay et al., 1987). The Dhruma Formation was subdivided into three units, including lower, middle and upper, by Bramkamp and Steineke (1952) and Arkell (1952). These units have been further subdivided by Vaslet et al. (1983), who proposed seven informal units (D1 to D7) based mainly on sedimentology and biostratigraphy (ammonites). Units D1 and D2 correspond to the lower Dhruma Formation sensu Bramkamp and Steineke (1952) and have been assigned informal names. The lowermost D1 unit, also called the Balum Member, has been assigned an early Bajocian age based on ammonites (Discites, Laeviuscula European zones of Enay et al., 1987; Enay and Mangold, 1994).
The first micropalaeontological study of the Dhruma Formation was carried out by Powers et al. (1966), who described eight foraminiferal zones. The lower part of the formation was assigned to the Haurania Zone based on two species: Haurania amiji and Haurania deserta of late Bajocian age (Powers et al., 1966). Subsequent work on foraminifera was performed by Hughes $(2004,2006$, 2009), who reported the following 13 species from the Dhruma Formation: Ophthalmidium spp., "Pfenderina" trochoidea, Satorina apuliensis, Trocholina elongata, Ammobaculites spp., Nautiloculina oolithica, "Pfenderina" salernitana, Redmondoides lugeoni, Redmondoides sp. cf. rotundata, Valvulina sp., Trochamijiella gollehstanehi, Parurgonia caelinensis and Pseudocyclammina sp. cf. lituus. AlDhubaib (2010) additionally reported Riyadhella elongata, Pseudomarssonella bipartita, Trocholina aptiensis, Meyendorffina bathonica, and several species of Neotrocholina and Andersenolina from the upper part of the Dhruma Formation.

The foraminifera from the limestone reservoirs of the Dhruma Formation have been studied by several Saudi Arabian Oil Company (Aramco) micropalaeontologists (e.g. Redmond, 1964; Hughes, 2009), but the microfauna from the lower shaley members has not been previously reported. The purpose of this study is to report a new finding of an 


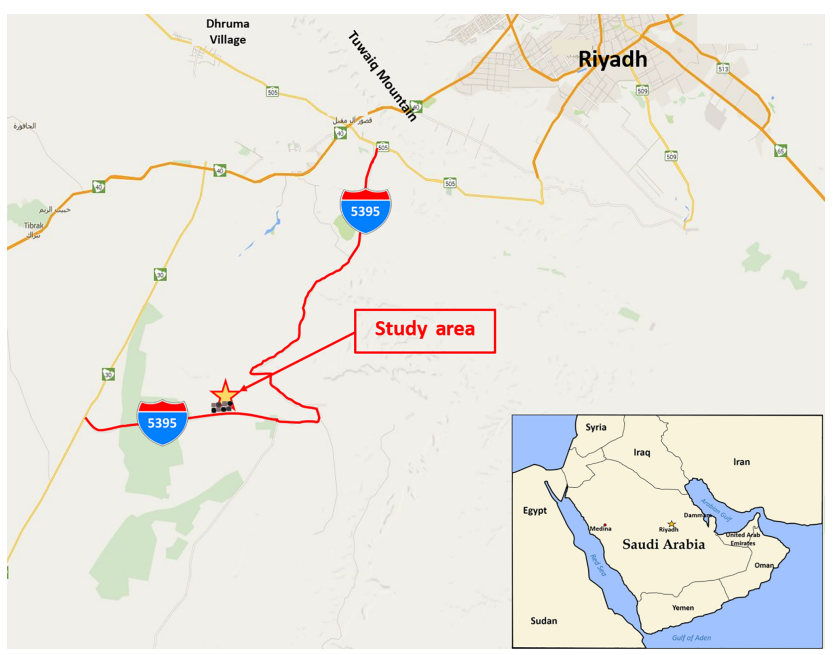

Figure 1. Location of the studied section.

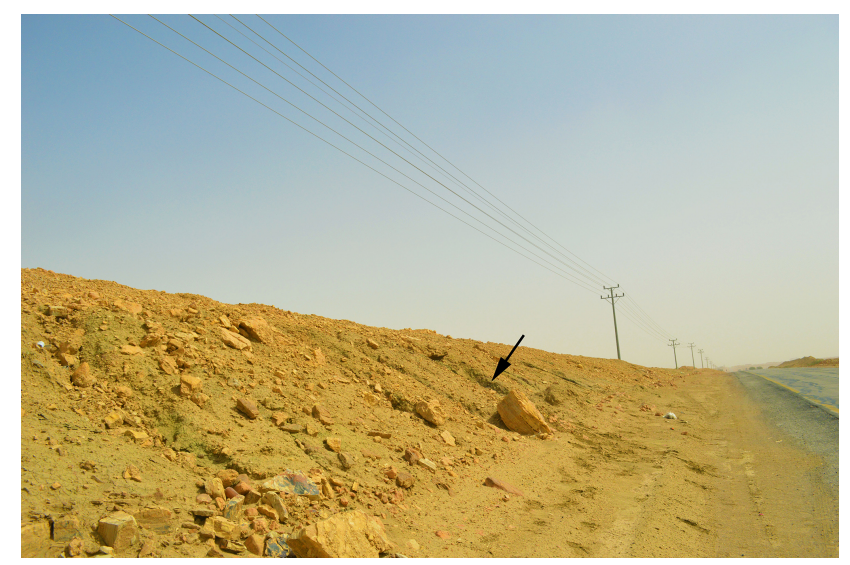

Figure 2. Road cut along Route 5395 at N $24^{\circ} 09^{\prime} 45^{\prime \prime}, \mathrm{E} 46^{\circ} 07^{\prime} 41^{\prime \prime}$, looking east. Arrow points to the green shale exposure.

assemblage of smaller agglutinated foraminifera present in the green shale of the basal D1 unit (Balum Member) of the Dhruma Formation.

\section{Material and methods}

The main emphasis of the study is the green shale of the lower Dhruma Formation belonging to the basal Balum (D1) Member. The green foraminifera-rich shale is exposed near the Dhibi limestone quarries located west of Riyadh (Fig. 1). A road cut along Road 5395 off Highway 30 (N24 $09^{\prime} 45^{\prime \prime}$, $\left.\mathrm{E} 46^{\circ} 07^{\prime} 41^{\prime \prime}\right)$ provides a fresh outcrop of green shale with interbedded brecciated limestone (Fig. 2). The basal member of the Dhruma Formation contains vuggy limestone collapse breccia that was formed as a result of the dissolution of evaporites, and therefore the depositional palaeoenvironment is here interpreted to be very shallow marine with hypersaline pools or lagoons.
The samples were disaggregated, washed over a $63 \mu \mathrm{m}$ sieve, and dried at the Center of Petroleum \& Minerals of the Research Institute, King Fahd University of Petroleum \& Minerals (KFUPM). To accelerate the disaggregation and washing process, samples were boiled with industrial soap, which helps in the dispersal and removal of muddy particles from the sand-size grains. The foraminifera were separated into faunal slides and photographed using a Nikon-1500 photomicroscope. Representative specimens were imaged using a model JSM-5900LV scanning electron microscope in the GeoSciences Department at KFUPM.

\section{Results}

The foraminiferal assemblage recovered from the green shale of the lower Dhruma Formation consists entirely of small agglutinated forms dominated by the genus Ammobaculoides, accompanied by rare specimens of Ammobaculites aff. agglutinans (d'Orbigny) and small trochamminids. Ammobaculoides specimens comprise $>97 \%$ of the total assemblage. Such an Ammobaculoides-dominated assemblage has not been previously reported from the Jurassic of Saudi Arabia. The entirely agglutinated nature and low diversity of the assemblage along with the presence of evaporates in the D1 Unit suggest restricted and stressed environmental conditions. The new species Ammobaculoides dhrumaensis n.sp. is described below.

\section{Systematic palaeontology}

The supra-generic classification of the agglutinated foraminifera follows Kaminski (2014).

\section{Class Foraminifera d'Orbigny}

Subclass Globothalamana Pawlowski, Holzmann \& Tyszka

Order Lituolida Lankester

Suborder Spiroplectamminina Mikhalevich

Family Spiroplectamminidae Cushman

Genus Ammobaculoides Plummer, 1932

Type species: Ammobaculoides nararroensis Plummer, 1932.

Ammobaculoides dhrumaensis n.sp. (Figs. 3, 4: 13)

Material: over 350 specimens.

Derivation of name: named after the Dhruma Formation of Saudi Arabia. 


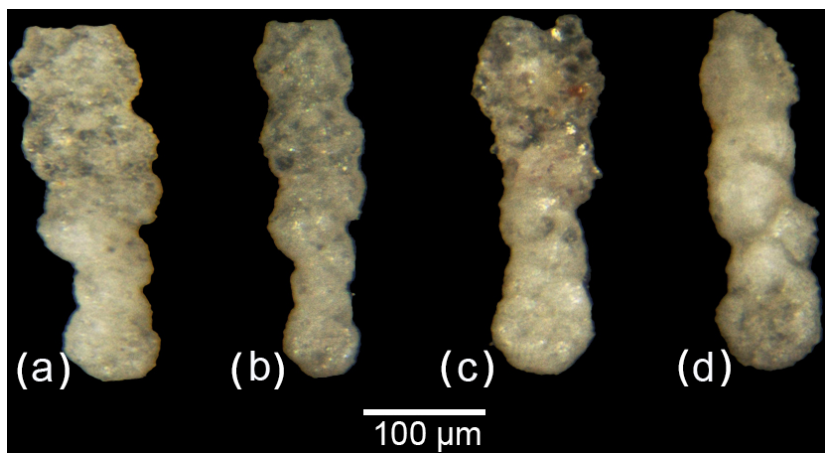

Figure 3. Light microscope images of paratypes of Ammobaculoides dhrumaensis n.sp.

Description: Test free, small, elongate, slightly compressed. Early chambers planispirally enrolled, consisting of two whorls with six chambers in the final whorl. The uncoiled part contains up to six chambers: initially with a pair of biserial to loosely biserial chambers, next becoming lax-uniserial, and finally uniserial. Sutures depressed. Wall agglutinated, silicified, insoluble in acid, surface smooth. Aperture terminal, central, oval, on a low shoulder on the final rectilinear chambers.

Remarks: Our specimens of Ammobaculoides dhrumaensis n.sp. most closely resemble the species Ammobaculoides primoris Komissarenko, 1977, from the upper Callovian of Western Siberia. The specimens illustrated by Komissarenko (1977) are morphologically variable, with about 11 to 12 chambers in the planispiral part (7-8 chambers in the final whorl), followed by an uncoiled portion that may be initially biserial, loosely biserial, or even lax-uniserial (sensu Kaminski et al., 2011). The Siberian form also includes specimens consisting only of a planispiral coil, and complete specimens display a distinct apertural neck. The largest of the specimens illustrated by Komissarenko has only four chambers in the uncoiled part. Our specimens from Saudi Arabia differ in possessing one fewer chamber in the final whorl of the planispiral part, lack an apertural neck, and have an uncoiled portion with as many as six chambers (Fig. 4: 1). Similar to the specimens from Siberia, the uncoiled portion may be initially biserial (Fig. 4: 2), loosely biserial (Fig. 4: 1), or lax-uniserial (Fig. 4: 3). Our specimens from Saudi Arabia differ in possessing lower chambers in the uncoiled portion, whereas the Siberian specimens may have chambers that are more elongated and may be higher than wide.

Type level: lower Bajocian, lowermost D1 (Balum) member, Dhruma Formation.

Type locality: road cut along Road 5395 off Highway $30\left(\mathrm{~N} 24^{\circ} 09^{\prime} 45^{\prime \prime}, \mathrm{E} 46^{\circ} 07^{\prime} 41^{\prime \prime}\right)$, Riyadh District, Saudi Arabia.

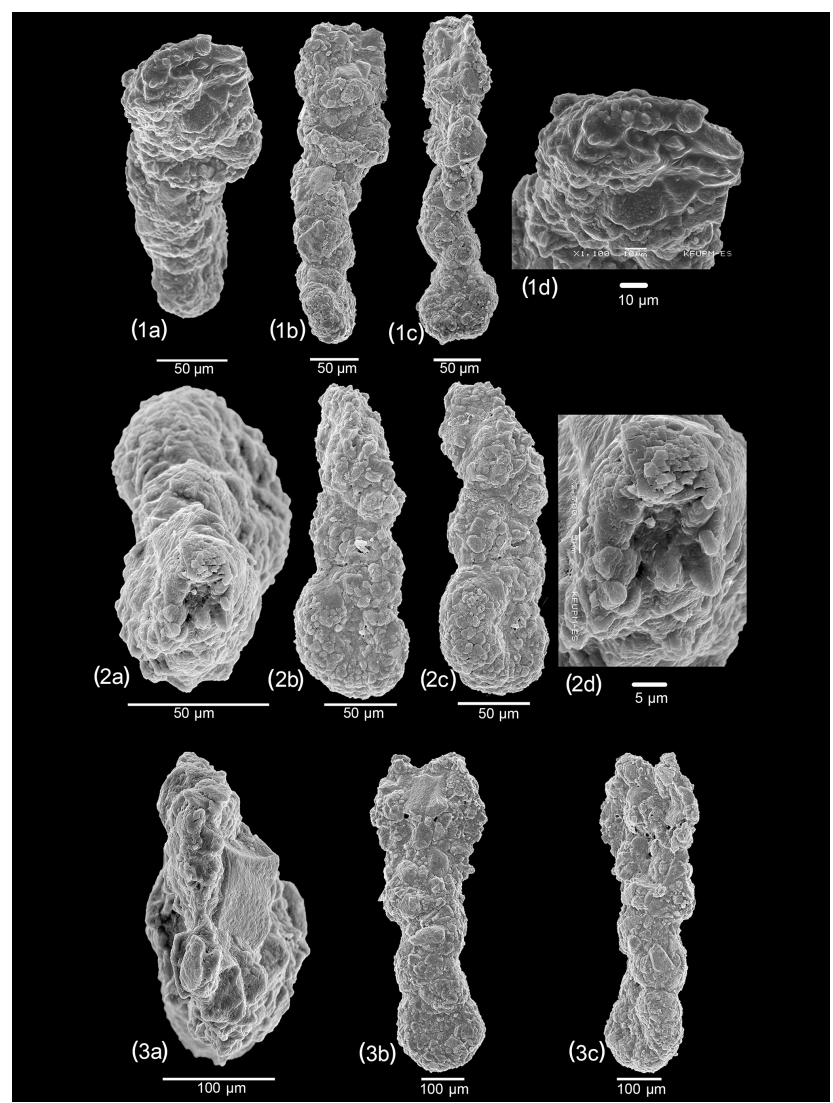

Figure 4. Scanning electron micrographs of Ammobaculoides dhrumaensis n.sp., from the basal D1 member of the Dhruma Formation, west of Riyadh. (1a-d) Paratype (EMRC 7/7C-9), loosely biserial specimen: (a) oblique terminal view; (b) edge view; (c) lateral view; (d) detail of aperture; scale bar $50 \mu \mathrm{m}$. (2a-d) Paratype (EMRC 7/7C-9), biserial specimen: (a) oblique terminal view; (b) lateral view; (c) oblique edge view; (d) detail of aperture; scale bar $50 \mu \mathrm{m}$. (3a-c) Holotype (EMRC 7/7C-8), lax-uniserial specimen: (a) terminal view; (b-c) lateral views; scale bar $100 \mu \mathrm{m}$.

Dimensions: Holotype - length $650 \mu \mathrm{m}$, maximum width $245 \mu \mathrm{m}$, width of spiral part $200 \mu \mathrm{m}$.

Type specimens: The holotype and figured paratypes have been deposited in the European Micropalaeontological Reference Centre (EMRC Cabinet 7, drawer 7) at Micropress Europe, AGH University of Science \& Technology, in Kraków, Poland.

\section{Discussion and conclusions}

Our finding of an Ammobaculoides-dominated assemblage in the lower Bajocian D1 (Balum) Member of the Dhruma Formation in Saudi Arabia constitutes the oldest reported occurrence of this genus. The oldest previously published report of Ammobaculoides is from the upper Callovian of 
Western Siberia (Komissarenko, 1977; Azbel and Grigalis, 1991). Our specimens bear some resemblance to Ammobaculoides primoris Komissarenko, but taking into account the geographical separation from Siberia and older stratigraphic occurrence, they are here described as a new species.

Data availability. The microscope slides have been deposited in the European Micropalaeontological Reference Centre (EMRC Cabinet 7, drawer 7) at Micropress Europe, AGH University of Science \& Technology, in Kraków, Poland. Access to the EMRC collections is by appointment. See www.micropresseurope.eu.

Competing interests. The authors declare that they have no conflict of interest.

Acknowledgements. We thank the Deanship of Scientific Research, KFUPM, for funding this project as part of the Research Group program under Grant number RG-1401. We thank G. Wyn Hughes (KFUPM; Hughes Micropaleo), Jenö Nagy (Oslo University), and an anonymous reviewer for kindly reading the manuscript. Scientific editing by Laia Alegret.

\section{References}

Al-Dhubaib, A. J.: Taxonomy and palaeoenvironments of Middle and Late Jurassic Foraminifera and its associations of Saudi Arabia, unpublished $\mathrm{PhD}$ thesis, University College London, 401 pp., 2010.

Arkell, W. J.: Jurassic ammonites from Jebel Tuwaiq, central Arabia, Philos. T. R. Soc. B, 36, 241-313, 1952.

Azbel, A. Y. and Grigalis, A. A. (Eds.): The Practical Manual of Microfauna of the USSR: Mesozoic Foraminifera, "Nedra" Publishers, Leningrad, 1991.

Bramkamp, R. A. and Steineke, M.: Stratigraphical introduction, in: Jurassic ammonites from Jebel Tuwaiq, central Arabia, edited by: Arkell, W. J., Philos. T. R. Soc. B, 236, 241-313, 1952.

Enay, R. and Mangold, C.: First zonation by ammonites of Saudi Arabia Jurassic, a reference for the Arabian Province, Geobios, Memoire Special, 17, 161-174, 1994.
Enay, R., Le Nindre, Y.-M., Mangold, C., Manivit, J., and Vaslet, D.: Le Jurassique d'Arabie Saoudite Centrale: nouvelles données sur la lithostratigraphie, les paléoenvironnements, les faunes d'ammonites, les ages et les correlations, edited by: Enay, R., Geobios, Memoire Special, 9, 13-65, 1987.

Hughes, G. W.: Middle to Upper Jurassic Saudi Arabian carbonate petroleum reservoirs: biostratigraphy, micropalaeontology and palaeoenvironments, GeoArabia, 9, 70-114, 2004.

Hughes, G. W.: Biofacies and palaeoenvironments of the Jurassic Shaqra Group of Saudi Arabia, Volumina Jurassica, 4, 89-90, 2006.

Hughes, G. W.: Using Jurassic Micropaleontology to determine Saudi Arabian carbonate paleoenvironments, in: Geologic Problem Solving with Microfossils: A volume in honor of Garry D. Jones, edited by: Demchuk, T. D. and Gary, A. C., SEPM Special Publication, 93, 127-152, 2009.

Kaminski, M. A.: The year 2010 classification of the agglutinated foraminifera, Micropaleontology, 61, 89-108, 2014.

Kaminski, M. A., Cetean, C. G., and Tyszka, J.: Nomenclature to describe the transition from biserial to uniserial chamber arrangement in agglutinated foraminifera, J. Micropaleontol., 30, 7-10, 2011.

Komissarenko, V. K.: The occurrence of the genus Ammobaculoides Plummer from the Upper Jurassic of the Western Siberian Lowlands, in: Biostratigraphic characteristics of Jurassic and Cretaceous Oil and Gas Bearing Deposits of Western Siberia, edited by: Braduchan, Yu. V., Trudy ZSNIGNI, 119, 58-65, 1977 (in Russian).

Plummer, H. J.: Ammobaculoides, a new foraminiferal genus, Am. Midl. Nat., 13, 86-88, 1932.

Powers, R. W., Ramirez, L. F., Redmond, C. D., and Elberg, E. L.: Geology of the Arabian Peninsula, Sedimentary geology of Saudi Arabia, U.S. Geological Survey Professional Paper, 560D, 1-147, 1966.

Redmond, C. D.: The foraminiferal family Pfenderinidae in the Jurassic of Saudi Arabia, Micropaleontology, 10, 251-263, 1964.

Vaslet, D., Manivit, J., Le Nindre, Y.-M., Brosse, J.-M., Fourniguet, J., and Delfour, J.: Explanatory notes to the geologic map of the Ar Riyad Quadrangle, Sheet 23H, Saudi Arabian Deputy Ministry for Mineral Resources, Geoscience Map GM-63, scale $1: 250,000,1983$. 